\title{
Selective advantage conferred by resemblance of aposematic mimics to venomous model
}

\author{
Frederico Gustavo Rodrigues França ${ }^{I^{*}}$, Vivian da Silva Braz ${ }^{2}$ \& Alexandre Fernandes Bamberg de Araújo ${ }^{3}$ \\ ${ }^{1}$ Universidade Federal da Paraíba, Centro de Ciências Aplicadas e Educação, Departamento de Engenharia e Meio \\ Ambiente, CEP 58297-000, Rio Tinto, PB, Brazil \\ ${ }^{2}$ Centro Universitário de Anápolis, Programa de Pós-Graduação em Sociedade, Tecnologia e Meio Ambiente, \\ Anápolis, GO, Brazil \\ ${ }^{3}$ Universidade Federal Rural do Rio de Janeiro, Instituto de Biologia, Departamento de Biologia Animal, 23851-970, \\ Seropédica, RJ, Brazil \\ *Corresponding author: Frederico Gustavo Rodrigues França, e-mail: fredericogrf@gmail.com
}

FRANÇA, F. G. R., BRAZ, V. S., ARAÚJO, A. F. B. Selective advantage conferred by resemblance of aposematic mimics to venomous model. Biota Neotropica. 17(3): e20170338. http://dx.doi.org/10.1590/1676-0611-BN-2017-0338

\begin{abstract}
Mimicry is an excellent example of how natural selection can act on color, morphology, and behavior of species. Herein we assess predation rates on coral snake mimics in Central Brazil, a region with many mimics but only a single model, to answer the following questions: (i) Do predators avoid attacking coral snake mimics? (ii) Does the degree to which mimics resemble their venomous model affect the frequency of predator attacks? (iii) Do predators attack different body regions in mimics with different color patterns? Our experiment was conducted in the Chapada dos Veadeiros National Park, in the municipality of Alto Paraíso de Goiás, state of Goiás, Brazil. To evaluate predation rates on the different mimic patterns, we made 2,400 clay snake replicas using pre-colored nontoxic plasticine and distributed them in open savanna landscapes within the park. A total of $164(6.83 \%)$ replicas were attacked by predators of snakes. Among these attacks, 121 were attacks by birds, and 43 were attacks by carnivorous mammals. Logistic regression and Fisher's exact test indicated that replicas with red, white, and black coloration are less likely to be attacked than were grey replicas, and coral snake replicas were attacked more often at the "head" end. Also, the greater the similarity to the pattern of venomous coral snakes, the rarer the attack on the replica. Our study underscores the strong selective force that protects coral snake mimics from predators. Our findings reinforce resemblance to the model as an extremely effective strategy in a complex natural system with only one model and numerous mimics.
\end{abstract}

Keywords: mimicry, coral snake, Central Brazil, predation.

\section{Vantagem seletiva atribuída à semelhança de mímicos aposemáticos ao modelo venenoso}

Resumo: O mimetismo é um ótimo exemplo de como a seleção natural pode agir sobre a coloração, morfologia e comportamento das espécies. Neste trabalho nós utilizamos as taxas de predação em mímicos de cobras corais no Brasil Central, uma região com muitos mímicos mas apenas um modelo, para responder as seguintes questões: (i) Os predadores evitam atacar os mímicos das cobras-corais? (ii) O grau de semelhança de cada mímico em relação ao modelo afeta a frequência de ataque dos predadores? (iii) A região do corpo na qual os predadores atacam varia entre os diferentes mímicos? O estudo foi realizado no Parque Nacional da Chapada dos Veadeiros, município de Alto Paraíso de Goiás, estado de Goiás, Brasil. Para avaliar as taxas de predação nos diferentes padrões, nós utilizamos 2400 réplicas construídas com massa de modelar pré-colorida e não tóxica e distribuídas em fitofisionomias abertas de Cerrado do Parque. Um total de 164 (6.83\%) réplicas foram atacadas por predadores de serpentes, sendo 121 réplicas atacadas por aves e 43 por mamíferos. A análise de regressão logística e o teste exato de Fisher indicaram que as réplicas com cores vermelha, preto e branco são menos propensas a serem atacadas do que as réplicas cinzas e que essas réplicas com cores de cobra-coral são mais atacadas na extremidade da "cabeça". Além disso, quanto maior a semelhança do padrão da cobra-coral verdadeira, menor a probabilidade da réplica ser atacada. Este estudo evidencia a grande força seletiva de serpentes corais sobre a proteção de serpentes miméticas e reforça a semelhança do modelo como uma estratégia extremamente eficiente em um sistema complexo com um modelo e vários mímicos.

Palavras-chave: mimetismo, cobra coral, Brasil Central, predação. 


\section{Introduction}

Mimicry is an excellent example of how natural selection can act on color, morphology, and behavior of species. In order to avoid predation, plants, invertebrates, and vertebrates have evolved a myriad of mimicry strategies worldwide (Ruxton et al. 2004). Coral snake mimicry systems enable the study of the selective pressures driving the evolution of mimicry in vertebrates and involve the following understandings. (i) Brightly banded neotropical snakes are mimics of elapid coral species. In spite of a previous debate, coral snake mimicry is widely supported by studies of geographic concordance (Greene \& McDiarmid 1981, Marques \& Puorto 1991, Harper \& Pfennig 2007), allopatric mimicry (Pfennig et al. 2001, Pfennig et al. 2007, Pfennig \& Mullen 2010, Akcali \& Pfennig 2014), and genetics and evolution (Harper \& Pfennig 2008, Pyron \& Burbrink 2009, Kikuchi \& Pfennig 2010, Pfennig et al. 2015). (ii) A wide range of mimics of poisonous species are protected from predation. This assumption was confirmed by various experiments with clay models (Brodie 1993, Buasso et al. 2006, Kikuchi \& Pfennig 2010). (iii) The success of avoiding predation increases with resemblance to the model. Brodie (1993) suggested some mimics would be less predated than others. Furthermore, he proposed that predation rate on mimics would decline as resemblance to the model increased. However, he stated that testing this hypothesis would be difficult because there are multiple models in his study area and suggested further experimentation on assemblages with multiple mimics and a single model pattern to address this issue. Pfennig \& Kikuchi (2012) demonstrated differences in predation rates among mimics of Lampropeltis elapsoides (Holbrook, 1838) (Colubridae), in which poor mimics are more susceptible to attacks than perfect or good mimics.

Herein we assess predation rates on coral snake mimics in Central Brazil, a region with many mimics but only a single model, to answer the following questions: (i) Do predators avoid attacking coral snake mimics? The hypothesis is that snakes with bright red, white, and black coloration are attacked less often than brown/grey snakes, as these colors work as an aposematic signal for natural predators of snakes, and predators avoid these colors even when the patterns presented are imperfect (Smith 1975, Greene \& McDiarmid 2005, Kikuchi \& Pfennig 2010). (ii) Does the degree to which mimics resemble their venomous model affect the frequency of predator attacks? The hypothesis is that mimics that closely resemble the pattern of venomous coral snakes (tricolor triads in red, white, and black along the entire body) will be less attacked than false-coral snakes with dissimilar patterns (imperfect patterns). The prediction is that predators, even if they generally avoid aposematic color snakes, can distinguish poor mimics from good ones in an aposematic system (Brodie 1993, Pfennig \& Kikuchi 2012). (iii) Does the body region that predators attack vary among mimics with different patterns? The hypothesis is that predators principally attack coral snakes and mimics in the head, to avoid possible injuries from a bite, whereas they attack harmless snakes in the body (Brugger 1989, Greene \& McDiarmid 2005).

\section{Material and Methods}

Our experiment was conducted in the Chapada dos Veadeiros National Park (CVNP) (13 ${ }^{\circ} 51^{\prime} \mathrm{S}$ to $14^{\circ} 10^{\prime} \mathrm{S}$ and $47^{\circ} 25^{\prime} \mathrm{W}$ to $\left.47^{\circ} 42^{\prime} \mathrm{W}\right)$, a 65,512 -ha protected area at the core of the Cerrado biome, in the municipality of Alto Paraíso de Goiás, northern Goiás state, central Brazil. Approximately 50 species of snakes live in the park (França \& Braz 2013), of which one species is venomous, Micrurus frontalis (Duméril, Bibron \& Duméril, 1854) (Elapidae). There are also nine coral snake mimics: Tantilla melanocephala (Linnaeus, 1758) (Colubridae), Apostolepis ammodites Ferrarezzi, Barbo \& Albuquerque, 2005 (Elapomorphini: Xenodontinae: Dipsadidae), Erythrolamprus aesculapii (Linnaeus 1758) (Xenodontini: Xenodontinae: Dipsadidae), Oxyrhopus guibei Hoge \& Romano 1977
(Pseudoboini: Xenodontinae: Dipsadidae), Oxyrhopus rhombifer Duméril, Bibron \& Duméril, 1854 (Pseudoboini: Xenodontinae: Dipsadidae), Oxyrhopus trigeminus Duméril, Bibron \& Duméril, 1854 (Pseudoboini: Xenodontinae: Dipsadidae), Oxyrhopus petolarius digitalis (Reuss, 1834) (Pseudoboini: Xenodontinae: Dipsadidae), juvenile Pseudoboa nigra (Duméril, Bibron \& Duméril, 1854) (Pseudoboini: Xenodontinae: Dipsadidae), and juvenile Boiruna maculata (Boulenger 1896) (Pseudoboini: Xenodontinae: Dipsadidae).

Snake replicas were made using pre-colored nontoxic plasticine (Acrilex) threaded onto a plastic tube and a wire to create an S-shape (following Brodie 1993). All snake models looked very similar to juvenile or adult snake species found in the CNPV. Replicas were $1.5 \mathrm{~cm}$ in diameter and $20 \mathrm{~cm}$ in length, and each replica had a "head" representing the anterior end of the snake, while the posterior end was anchored into the ground by wire. Six different color patterns were constructed following the classification proposed by Savage \& Slowinski (1992): (A) TT (the model/perfect mimic, a tricolor triad characteristic of the venomous coral snake $M$. frontalis and mimics such as Simophis rhinostoma, O. trigeminus, and O. guibei), (B) TD (tricolor dyad characteristic of E. aesculapii), (C) TSB (black diamond blotches (outlined in yellow) on red, characteristic of the imperfect mimic O. rhombifer), (D) BIR (red and black bicolor, characteristic of O. petola), (E) UCD (unicolor in red with black nuchal collar characteristic of non- or mildly venomous rear-fanged colubrid snakes of the genera Apostolepis and Phalotris and juveniles of Clelia) and (F) CTR (uniformly gray control, similar to non-venomous colubrid snakes of the genera Chironius and Erythrolamprus) (Figure 1).
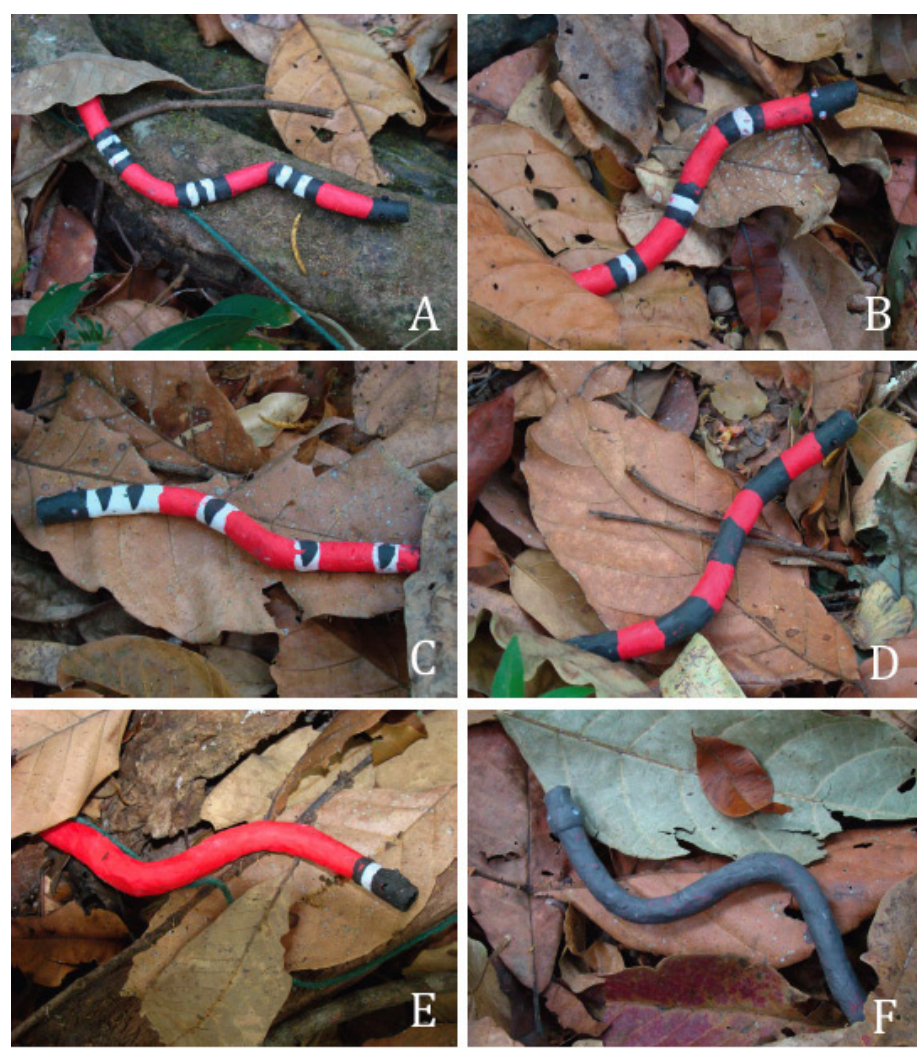

Figure 1. Clay model replicas of six snake patterns. The patterns are: A- TT (tricolor triad), B- TD (tricolor diad), C- TSB (black diamond blotches (outlined in yellow) on red), D- BIR (red and black bicolour), E- UCD (unicolor in red with black nuchal collar), and F- CTR (uniformly gray control). 
To evaluate predation rates on the different mimic patterns, we used 2,400 clay replicas. We distributed 600 clay replicas ( 100 of each pattern) during each of four months (May, June, September, and November 2007). These 600 clay replicas were distributed randomly in four transects, in commonly open landscapes within the CVNP, such as grasslands and montane savannas. The transects were at least $30 \mathrm{~km}$ apart from one another, and replicas inside each transect were placed at least $10 \mathrm{~m}$ apart. Transects were not located exactly in the same places each month but were allocated in the same region of the CVNP, with the following geographical

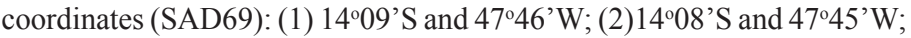
(3) $14^{\circ} 06^{\prime} \mathrm{S}$ and $47^{\circ} 38^{\prime} \mathrm{W}$; (4) $14^{\circ} 05^{\prime} \mathrm{S}$ and $47^{\circ} 37^{\prime} \mathrm{W}$. Each replica remained in the field for seven consecutive days, after which any attack marks were registered and the replica was then removed. Replicas were not reused in subsequent months.

We did not attempt to compensate for the relative conspicuousness of the models in the environment because previous studies on aposematic snakes demonstrated that there were no differences in attack rates when snakes had different backgrounds (Brodie 1993, Wüster et al. 2004, Buasso et al. 2006). All replicas in each transect were in place for 10 consecutive days, after which we checked replicas for evidence of predator attacks. We counted only marks made by birds ( $\mathrm{V}$ - and U-shaped) and carnivorous mammals (Canidae, Didelphidae, Mustelidae) (teeth-shaped) as predator attacks. Marks made by rodents and arthropods were ignored. Replicas with evidence of more than one predator attack were scored for only a single predator attack based on Brodie (1993). All marked replicas were preserved and housed in the Laboratório de Ecologia Animal of Universidade Federal da Paraíba (UFPB).

We employed logistic regression to model differences in predation rates among coloration patterns and estimate the odds of a predator attack for each pattern (Tabachnick \& Fidell 2007). The binary logistic

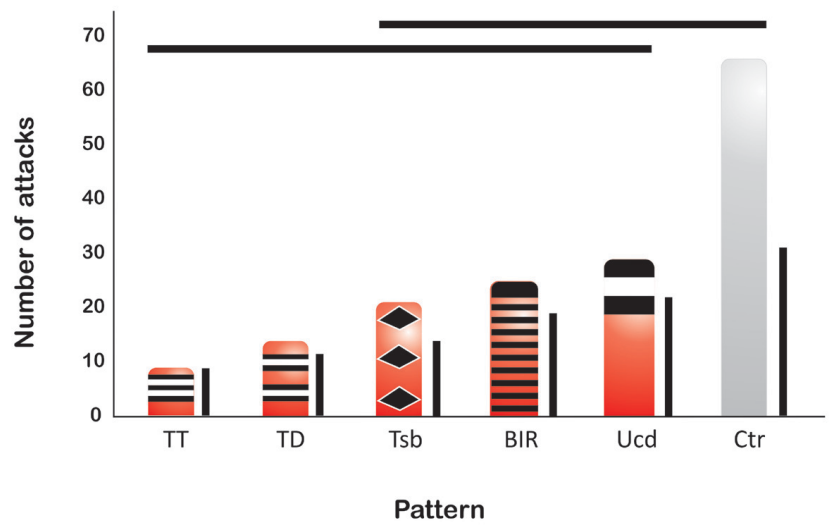

Figure 2. The number of attacks by natural predators on each of six patterns of snakes. Solid lines above bars indicate groups that differ significantly from each other by Kruskal-Wallis analysis. Solid lines on the side of the bars denote the number of attacks on the head of clay models. model was used to estimate the probability of a binary response based on one or more predictor (or independent) variables (Tabachnick \& Fidell 2007). To perform logistic regression, we considered predation a binary dependent variable $(0=$ non attack, $1=$ attack $)$ tested against the different color patterns of replicas of snakes (TT, TD, TSB, BIR, UCD, CTR). Each attacked replica was computed as 1 , regardless of the type of predator or number of attacks. We tested the null hypothesis that the color patterns did not influence predation on snake replicas. Also, we used Fisher's exact test to determine whether the body region attacked by predators differed by pattern. We carried out statistical analyses using R ( R Development Core Team 2010), with a significance level of 5\% to reject the null hypothesis. Logistic regression was done using the $1 \mathrm{mr}$ function of the rms package (Harrell 2011).

\section{Results}

Of the 2,400 clay models, $164(6.83 \%)$ were attacked by predators of snakes. Among these attacks, $121(74 \%)$ were inflicted by birds and 43 $(26 \%)$ were attacks by carnivorous mammals. In addition to marks on the models, there was other evidence of predators near some models, such as foot imprints, feathers, or fur. We recorded attacks on nine models of pattern TT, 14 of TD, 21 of TSB, 25 of BIR, 29 of UCD, and 66 of CTR. Logistic regression indicated that pattern significantly affected the probability of being predated (likelihood ratio $\mathrm{X}^{2}=71.18, \mathrm{df}=5, p<0.0001$ ) and estimated the odds of being attacked for each pattern (Table 1). We observed that CTR pattern was more attacked than any other red, black and white patterns and also an increase in predation odds as resemblance to the model decreased (Figure 2). There were more attacks on the head than on the body for patterns TT (Fisher's exact test, $p=0.004$ ), BIR (Fisher's exact test, $p=0.013$ ), and UCD (Fisher's exact test, $p=0.002$ ), but the number of attacks did not significantly differ between the head and body $(p<0.05)$ for TD (Fisher's exact test, $p=0.055)$, TSB (Fisher's exact test, $p=0.183$ ), and CTR (Fisher's exact test, $p=0.7$ ).

\section{Discussion}

We observed that models with patterns that mimicked coral snakes were less predated than were models that did not mimic coral snakes; there was a direct relationship between predation and resemblance to the model, and predators appeared to target the heads of mimics more often. The single venomous model in the CVNP, the coral snake $M$. frontalis, conferred some degree of protection from predators to an ample range of imperfect mimics. Coral snakes (TT) combine dangerous venom with difficulty of capture, secretive habits, and defensive behavior, making them excellent models for mimicry (Greene \& McDiarmid 1981). Imperfect mimics receive some protection even in allopatric regions (Pfennig \& Mullin 2010). Moreover, frequency-dependent selection predicts that if harmless and edible perfect mimics become too common, predators will learn to ignore the warning coloration. Very similar morphs should receive the best protection, leading to the possibility of stable polymorphisms (Mallet \& Joron 1999).

Table 1. Summary of the Logistic regression results of predation in intensity in snake models. The intercept includes the pattern TT.

\begin{tabular}{|c|c|c|c|c|c|}
\hline & Parameter Estimate & Standard Error & Wald Chi-Square & Pr $>$ Chi-Sqr & Odds Ratio \\
\hline Intercept & -3.7715 & 0.3371 & -11.19 & $<0.0001$ & 0.02 \\
\hline $\mathrm{TD}$ & 0.4547 & 0.4332 & 1.05 & 0.2939 & 1.58 \\
\hline TSB & 0.8785 & 0.4049 & 2.17 & 0.0300 & 2.41 \\
\hline BIR & 1.0634 & 0.3954 & 2.69 & 0.0072 & 2.90 \\
\hline UCD & 1.2226 & 0.3884 & 3.15 & 0.0016 & 3.40 \\
\hline CTR & 2.1500 & 0.3631 & 5.92 & $<0.0001$ & 8.58 \\
\hline
\end{tabular}


The small number of attacks on TT, TD, and TSB patterns agrees with the results of a previous study in the Argentinian Chaco (Buasso et al. 2006). Furthermore, the UCD result was similar to findings in Costa Rica, in which the collar pattern was the most attacked coral snake phenotype (Brodie 1993). Our findings support Brodie's (1993) prediction and suggest that the most similar phenotypes enjoy a selection advantage for predator deterrence over imperfect mimics. Kikuchi \& Pfennig (2010) changed the proportion and the order of the colors and demonstrated no difference in predation between a perfect mimic and a good one (with a different order of colors), but both were less predated than a poor mimic (with both a different proportion and order of colors). These results confirm Brodie's prediction that predation on mimics will increase as difference to the model increase. Kikuchi \& Pfennig (2013) also predicted loose selection (i.e., an increase in predation rate) on the proportions of dorsal colors, a generalization of the deadly model scenario. Although our data cannot confirm any specific assumptions regarding colors, our results match the prediction of an increase in predation rate as resemblance with the model decreased, using the natural assemblage of species as a proxy for a resemblance gradient. Finally, regarding the higher predation on CTR, most snakes in neotropical assemblages are plain brown or grey, and all previous studies have found the highest rates of attacks on control patterns (Brodie 1993, Buasso et al. 2006).

The attacks directed to the head end instead the body portion in aposematic (red, white, and black) replicas are evidence that the predators recognize them as potentially dangerous snakes. Advantages for head-first attack include a decrease in the probability of incurring injury when handling dangerous prey, such as deadly coral snakes, and a reduction in swallowing time (Greene 1976).

Our study underscores the strong selective force protecting coral snake mimics from predators. Although all mimic phenotypes appear to have an advantage over gray-colored snakes, selection favors the best mimics. Our findings reinforce resemblance to the model as an extremely effective strategy in a complex natural system with only one model and a variety of mimics. Even imperfect mimics were less predated than non-coral snakes, revealing that even imperfect mimicry carries an advantage. This result confirmed previous assumptions regarding the avoidance of good mimics (Greene \& McDiarmid 2005, Kikuchi \& Pfennig 2013) and suggests that this evolutionary strategy may be widespread in dissimilar neotropical environments.

\section{Acknowledgments}

The authors are grateful to Daniel Rios de Magalhães Borges and ICMbio for work permits in the Chapada dos Veadeiros National Park. We thank Santos Balbino, Davi Pantoja, and Iubatã Farias for their generous help during fieldwork. We thank Ailton Maciel for help with the figures. We also thank the National Counsel of Technological and Scientific Development $(\mathrm{CNPq})$ for a graduate scholarship.

\section{Author Contributions}

Frederico Gustavo Rodrigues França: Substantial contribution in the concept and design of the study; Contribution to the acquisition of data; analysis and interpretation of data; manuscript preparation and critical review adding intellectual content.

Vívian da Silva Braz: Substantial contribution in the concept and design of the study; Contribution to the acquisition of data; analysis and interpretation of data; manuscript preparation and critical review adding intellectual content.

Alexandre Fernandes Bamberg de Araújo: Substantial contribution in the concept and design of the study; Contribution to the analysis and interpretation of data and critical review adding intellectual content.

\section{Conflicts of interest}

The authors declare that they have no conflict of interest related to the publication of this manuscript.

\section{References}

AKCALI, C.K. \& PFENNIG, D.W. 2014. Rapid evolution of mimicry following local model extinction. Biol. letters 10(6):20140304. http://dx.doi.org/10.1098/ rsb1.2014.0304

BRODIE, E.D., iii. 1993. Differential Avoidance of Coral Snake Banded Patterns by Free-Ranging Avian Predators in Costa Rica. Evolution 47(1):227-235 http://dx.doi.org/10.1111/j.1558-5646.1993.tb01212.x.

BRUGGER, K.E. 1989. Red-tailed hawk dies with coral snake in talons. Copeia 1989(2):508-510. http://dx.doi.org/10.2307/1445456

BUASSO, C.M., LEYNAUD G.C. \& CRUZ, F.B. 2006. Predation on snakes of Argentina: Effects of coloration and ring pattern on coral and false coral snakes. Stud. Neotrop. Fauna E. 41(3):183-188. http://dx.doi.org/10.1080/01650520600630725

FRANÇA, F.G.R. \& BRAZ, V.S. 2013. Diversity, activity patterns, and habitat use of the snake fauna of Chapada dos Veadeiros National Park in Central Brazil. Biota Neotropica 13(1):74-84 http://www.biotaneotropica.org.br/v13n1/pt/ abstract?article+bn01313012013 (last access in 24/02/2017). http://dx.doi. org/10.1590/S1676-06032013000100008

GREENE, H.W. 1976. Scale overlap, a directional sign stimulus for prey ingestion by ophiophagous snakes. Z. Tierpsychol. 41(2):113-120. http://dx.doi. org/10.1111/j.1439-0310.1976.tb00473.x

GREENE, H.W. \& MCDIARMID, R.W. 1981. Coral snake mimicry: does it occur? Science 213(4513):1207-1212. http://dx.doi.org/10.1126/science.213.4513.1207

GREENE, H.W. \& MCDIARMID, R.W. 2005. Wallace and Savage: heroes, theories and venomous snake mimicry. In Ecology and evolution in the tropics: a herpetological perspective (M. Donnelly, B. Crother, C. Guyer, M.H. Wake, \& M. E. White, eds.). University of Chicago Press. Chicago, p.190-208.

HARPER, G. R., jr \& PFENNIG, D. W. 2007. Mimicry on the edge: why do mimics vary in resemblance to their model in different parts of their geographical range? P. Roy. Soc. B-Biol. Sci. 274:1955-1961. http://dx.doi.org/dx.doi.org/10.1098/ rspb.2007.0558

HARPER, G. R., jr \& PFENNIG, D. W. 2008. Selection overrides gene flow to break down maladaptive mimicry. Nature 451:1103-1106. http://dx.doi org/10.1038/nature06532

HARRELL, F.E., Jr. 2011. rms: Regression Modeling Strategies. R package version 3.3-0. http://CRAN.R-project.org/package=rms (last access in 24/02/2017)

KIKUCHI, D.W. \& PFENNIG, D.W. 2010. Predator cognition permits imperfect coral snake mimicry. Am. Nat. 176(6):830-834. http://dx.doi.org/10.1086/657041

KIKUCHI, D.W. \& PFENNIG, D.W. 2013. Imperfect mimicry and the limits of natural selection. Q. Rev. Biol. 88(4):297-315. http://dx.doi.org/10.1086/673758

MALLET, J. \& JORON, M.1999. Evolution of Diversity in Warning Color and Mimicry: Polymorphisms, Shifting Balance, and Speciation. Annu. Rev. Ecol. Syst. 30:201-233. http://dx.doi.org/10.1146/annurev.ecolsys.30.1.201

MARQUES, O.A.V. \& PUORTO, G. 1991. Padrões cromáticos, distribuição e possível mimetismo em Erythrolamprus aesculapii (Serpentes, Colubridae). Mem. Inst. Butantan 53(1): 127-134.

PFENNIG, D.W., HARCOMBE, W.R. \& PFENNIG, K. S. 2001. Frequency-dependent Batesian mimicry. Nature 410(6826): 323. http://dx.doi.org/10.1038/35066628

PFENNIG, D. W., jr, G.R.H., BRUMO, A.F., HARCOMBE, W.R. \& PFENNIG, K.S 2007. Population differences in predation on Batesian mimics in allopatry with their model: selection against mimics is strongest when they are common. Behav. Ecol. Sociobiol. 61: 505-511. http://dx.doi.org/10.1007/s00265-006-0278-x

PFENNIG, D.W. \& MULLEN, S.P. 2010. Mimics without models: causes and consequences of allopatry in Batesian mimicry complexes. P. Roy. Soc. B-Biol. Sci. 277:2577-2585. http://dx.doi.org/10.1098/rspb.2010.0586

PFENNIG, D. W., \& KIKUCHI, D. W. 2012. Competition and the evolution of imperfect mimicry. Curr. Zool. 58(4): 608-619. http://dx.doi.org/10.1093/ czoolo/58.4.608 
PFENNIG, D.W., AKCALI, C.K. \& KIKUCHI, D.W. 2015. Batesian mimicry promotes pre- and postmating isolation in a snake mimicry complex. Evolution 69(4): 1085-1090. http://dx.doi.org/10.1111/evo.12624

PYRON, A.R. \& BURBRINK, F.T. 2009. Lineage diversification in a widespread species: roles for niche divergence and conservatism in the common kingsnake, Lampropeltis getula. Mol. Ecol. 18(16): 3443-3457. http://dx.doi.org/10.1111/ j.1365-294X.2009.04292.X

R DEVELOPMENT CORE TEAM. 2010. R: A language and environment for statistical computing. R Foundation for Statistical Computing, Vienna, Austria. ISBN 3-900051-07-0, URL http://www.R-project.org.

RUXTON, G.D., SHERRATT, T.N. \& SPEED, M.P. 2004. Avoiding Attack: The Evolutionary Ecology of Crypsis, Warning Signals and Mimicry. Oxford University Press, Oxford.

SAVAGE, J.M. \& SLOWINSKI, J.B. 1992 The coloration of the venomous coral snakes (family Elapidae) and their mimics (families Aniliidae and Colubridae). Biol. J. Linn. Soc. 45:235-254. http://dx.doi.org/10.1111/j.1095-8312.1992.tb00642.x
SMITH, S.M. 1975. Innate recognition of coral snake pattern by a possible avian predator. Science 187:759-760. http://dx.doi.org/10.1126/science.187.4178.759

TABACHNICK, B.G. \& FIDELL, L.S. 2007. Using Multivariate Statistics (5th ed.). Allyn and Bacon, New York.

WÜSTER, W., ALLUM, C.S.E., BJARGARDÓTTIR, I.B., BAILEY, K.L., DAWSON, K.J., GUENIOUI, J., LEWIS, J., MCGURK, J., MOORE, A.G., NISKANEN, M. \& POLLARD C.P. 2004. Do aposematism and Batesian mimicry require bright colours? A test, using European viper markings. P. Roy. Soc. B-Biol. Sci. 271:2495-2499. http://dx.doi.org/10.1098/rspb.2004.2894

Received: 07/03/2017

Revised: 04/08/2017

Accepted: 09/08/2017

Published online: 31/08/2017 